\title{
Nosemosis'in (nosematosis) bal arısı (Apis mellifera) midesine etkileri üzerine histokimyasal gözlemler
}

\author{
Ahmet CEYLAN ${ }^{1, a^{*}}$, Ögge ÖZGENÇ ${ }^{1, b}$, Füsun ERHAN ${ }^{1, c}$, Sedat SEVİN ${ }^{2, d}$, Ender YARSAN ${ }^{2, e}$ \\ ${ }^{1}$ Ankara Üniversitesi, Veteriner Fakültesi, Histoloji-Embriyoloji Anabilim Dal, Ankara, Türkiye \\ ${ }^{2}$ Ankara Üniversitesi, Veteriner Fakültesi, Farmakoloji ve Toksikoloji Anabilim Dal, Ankara, Türkiye

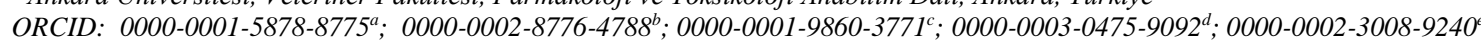

\section{MAKALE BILGISI / \\ ARTICLE \\ INFORMATION: \\ Geliş / Received: \\ 23 Mart 20 \\ 23 March 20 \\ Kabul / Accepted: \\ 22 Nisan 20 \\ 22 April 20}

Anahtar Sözcükler:

Ar1

Histokimya

Mukosubstans

Nosemosis

Keywords:

Honey bee

Histochemistry

Mucosubstances

Nosemosis
ÖZET:

Nosemosis, ergin bal arılarında görülen (Apis mellifera) ve microsproidea etkenlerinden Nosema apis ve Nosema ceranae'nin neden olduğu önemli bir hastalıktır. Hastalık mide (orta mide) mukozasında sindirim ve metabolik bozukluklara neden olan kritik değişikliklere yol açabilir. Bu çalışmada sağlıklı ve enfekte işçi arıların mide mukozasının histokimyasal özellikleri ile birlikte mukozanın ve peritrofik membranın yapısındaki değișikliklerin karşılaştırılması amaçlandı. Doku örnekleri Kalecik/Ankara bölgesindeki kolonilerden toplanan sağlıklı ve enfekte işçi arılardan alındı. Doku örnekleri, \% 10 nötr tamponlu formalin çözeltisi içinde tespit edildi, parafine gömüldü ve $5 \mu \mathrm{m}$ kalınlığında kesitler alındı. Kesitler, genel morfolojik değişiklikleri ortaya çıkarmak için Mallory'in üçlü boyaması, nötr mukosubsansları, asit ve sülfat mukosubsanslarını tanınmlamak içinse periyodik asit-Schiff, Alcian blue ve Toluidine blue ile boyandı. Mide epitelinin analizi, bazı hücrelerin çekirdeklerinin ortadan kaybolduğunu, bu hücrelerin sitoplazmalarında çeşitli boyutlardaki yoğun bir vakuolleşmenin hakim olduğunu, hücre sınırlarının açıkça belirlenemediğini ve hücre zarlarının çoğunun parçalandığını gösterdi. Histokimyasal analiz, karboksilik gruplara sahip ve siyalik asit bakımından zengin mukosubtans üretiminde bir azalmayı ortaya koydu. Sonuçlarımız bu sekresyonun azalmasında hangi mekanizmaların yer aldığını açıklamak için yeterli değildir. Bununla birlikte, nosemosisin besin bloke edici etkisi ve enfekte epitel hücrelerinin ölümünün mukosubstans üretimi üzerine olumsuz etkileri olabileceği düşünülmektedir.

\section{Histochemical observations on the effects of nosemosis (nosematosis) on honey bee (Apis mellifera) midgut}

\begin{abstract}
:
Nosemosis is a serious disease of adult honey bees (Apis mellifera) caused by (Microsporidia species) Nosema apis and Nosema ceranae. The disease may lead critical changes in midgut mucosa that cause digestive and metabolic disorders. In this study we aimed to describe the histochemical characteristics as well as the changes of peritrophic membrane and mucosa of the healthy and infected honey bees midgut. Tissue samples were taken from healthy and infected workers from the colonies in Kalecik/Ankara. The samples were fixed in $10 \%$ neutral buffered formalin solution, embedded in paraffin and cut with a microtome to $5 \mu \mathrm{m}$ thick sections. Slides were stained with the Mallory's trichrome stain for revealing general morphological changes and for describing neutral mucosubstances, acid and sulphate mucosubstances we used the periodic acid-Schiff, Alcian blue and Toluidine blue. Analysis of the midgut epithelium showed that some cells were with invisible nuclei, the cytoplasm of these cells was densely granulated with vacuoles of various sizes, while cell boundaries were not clearly marked and most cell membranes had been degraded. Histochemical analysis revealed a decrease in the production of mucosubstances with carboxylic groups and rich in sialic acid. Our results were not sufficient to explain which mechanisms are involved on that reduction of secretion. However, it is thought that nosemosis has a nutrient blocking effect and death of infected epithelial cells may have negative effects on mucosubtance production.
\end{abstract}




\section{Giriş}

İlk defa Enoch Zander tarafından tanımlanan nosemosis hastalığının etkenleri, Nosema apis (1) ve Nosema ceranae (2) olarak bilinmektedir. Tüm dünyada görülebilen hastalık bal üretimi üzerinde oluşturduğu olumsuz etkilere bağlı olarak ekonomik kayıplara neden olmaktadır. Her iki patojen de zorunlu, hücre içi, microsporidia etkenleri olup, ergin arıların mide epitel hücrelerine yerleşerek etki göstermekte, meydana gelen sindirim bozuklukları ve malnütrisyona bağlı olarak arı ömrünü azaltmakta ve arıların bal üretim kapasiteleri düşmektedir (3). Bununla birlikte hastalığın özellikle akut dönemde yüksek oranda koloni kaybına yol açtığı ve kolonide kalan bireylerin ise sağlık yönünden çok zayıf düştüğü bilinmektedir (4).

Bal arısında ön-mide yutak, yemek borusundan oluşurken; orta-mide ventrikülüs/gerçek mideden; arka-mide ise ileum ve rektum olarak iki parçadan meydana gelmektedir (5). Gerçek mide, polen sindiriminin ve emiliminin gerçekleştiği primer organ olarak kabul edilirken ileum ve rektumun ise çoğunlukla su ve iyonların emiliminden ve osmotik kontrolden sorumlu olduğu düşünülmektedir (6).

Mide ve bağırsak mukozasının birçok bal arısı patojenine karşı bir engel ve immun yanıt oluşturduğu bilinmektedir (7). Bu engel mekanizması mide mukozasına ait hücreler tarafından salgılanan, glikozaminoglikanlar, glikoproteinler ve proteinlerden oluşan peritrofik membran olarak adlandırılan bir yapı tarafindan şekillendirilir $(6,8)$. PM, omurgalı canlılardaki sindirim kanalının yüzeyini kaplayan mukustan zengin örtü benzeri bir yapıya sahiptir. PM, mide epitelini, mide içeriğinden ayırarak epitel için bir koruyucu katman görevini üstlenmektedir. Ayrıca beslenme esnasında yutulan patojenlere ve toksinlere karşı ilk engel olarak da nitelendirilmektedir $(8,9)$. Sağliklı bir mide mukozasına ait epitel hücrelerinin ve peritrofik membranın homojen bir bütünlük göstermesi gerektiği bildirilmiştir (7). Bal arısı patojenleri tarafından saldırıya uğrayan ve enfekte edilen ilk bölgeler arasında yer alan mide mukozasının epitel hücrelerinin dejeneratif değişikler gösterdiği ve peritrofik membranın bütünlüğünü kaybettiği bilinmektedir (10).

Bal arılarının normal gelişimlerini tamamlayabilmeleri ve sağlıklı kolonilerin devamlılı̆g için polenler vasıtasıyla alınan besin maddelerinin sindirim kanalında etkili bir şekilde emilimi büyük bir önem arz etmektedir. Hücre içi patojenler, hayatta kalmaları için güvenli bir sığınak oluşturmak amacıyla konakçı hücrelerin hücresel mekanizmalarını değiştirerek besin maddelerinin emilimini azalmasına neden olmaktadır. (11). Bu değişikliklere bağlı olarak özellikle mide epitel hücrelerinin yıkımlanmasından dolayı metabolizma faaliyetleri azalmaktadır. Bu durum sonucunda arı vücudunda protein emilimi arttı̆̆ından, sindirim enzimlerinin üretimi yok denecek seviyelere düşer ve enfekte arı açlıktan ölebilmektedir.

Ülkemizde yerli bal arısı ırklarımızın tanımlanmasına ve nosemosisin teşhisi ve dağılımına yönelik birçok morfolojik çalışma ve saha çalışması hâlihazırda bulunmaktadır $(12,13,14,15,16,17,18)$. Ancak nosemosisin ülkemizdeki bal arısı kolonilerinin üzerinde oluşturduğu etkilerin histomorfolojik ve histokimyasal olarak incelenmesine yönelik çalışmaların oldukça sınırlı olduğu hatta yok denecek kadar az olduğu görülmektedir. Bu çalışmada sağlıklı ve nosemosisli işçi arıların mide mukozasının histokimyasal ve histomorfolojik özellikleri ile birlikte mide mukozasında ve peritrofik membranın yapısında meydana gelen değişikliklerin karşılaştırılması amaçlandı.

\section{Gereç ve Yöntem}

Işık mikroskobik incelemeler için Kalecik/Ankara bölgesindeki kolonilerden toplanan sağliklı $\left(\mathrm{n}_{=} 20\right)$ ve enfekte $\left(n_{=} 20\right)$ işçi arılardan mide örnekleri alındı. İlk olarak işçi arılar on dakika boyunca $+4{ }^{\circ} \mathrm{C}$ 'de tutularak duyu yitimi (anestezi) işlemi gerçekleştirildi. Takiben sindirim kanalının abdomen bölümünü ortaya çıkarmak için iki adet pens yardımı ile toraks ve son abdomenin uç bölgesinden tutularak dikkatli bir şekilde birbirlerinden ayrılması sağlandı. Sonrasında hastalıklı olduğu makroskobik olarak tespit edilen işçi arılardan alınan örneklere ait içerik nosemosis etkenin varlığını tespit etmek amaciyla Ringer's solüsyonu ile muamele edilerek Dünya Hayvan Sağlı̆̆ı Örgütünün (OIE) belirlemiş olduğu kılavuzun basamakları uygulanarak incelendi (Şekil 1) (19). Sağlıklı olduğu tespit edilen işçi arılardan ve enfekte arılardan alınan örnekler \%10 tamponlu nötral formalinde 18 saat süre ile tespit edildikten sonra sırasıyla dereceli alkollerden ve ksilolden geçirilerek paraplasta bloklandı. Bloklardan alınan $5 \mu$ m'lik kesitlere genel morfolojik yapıyı ortaya koymak amacıyla Crossmon tarafından modifiye edilen Mallory’nin üçlü boyaması uygulandı 
(20). Genel olarak polisakkaritlerin gösterilmesi için periyodik asit-Schiff (PAS) (nötral mukosubstans), Alcian blue (AB) $\mathrm{pH} 2.5$ (karboksilli ve sülfatlı asidik mukosubstans), PAS/AB pH 2.5 (nötral ve asidik mukosubstans) kombinasyonu ve Toluidine blue (TB) (asidik mukosubstans) boyaması yapıldı (21). Son olarak tüm örnekler Leica DM 2500 model araştırma mikroskobu ile incelenerek dijital mikroskop kamerası (Leica DFC450) ile fotoğraflandı.
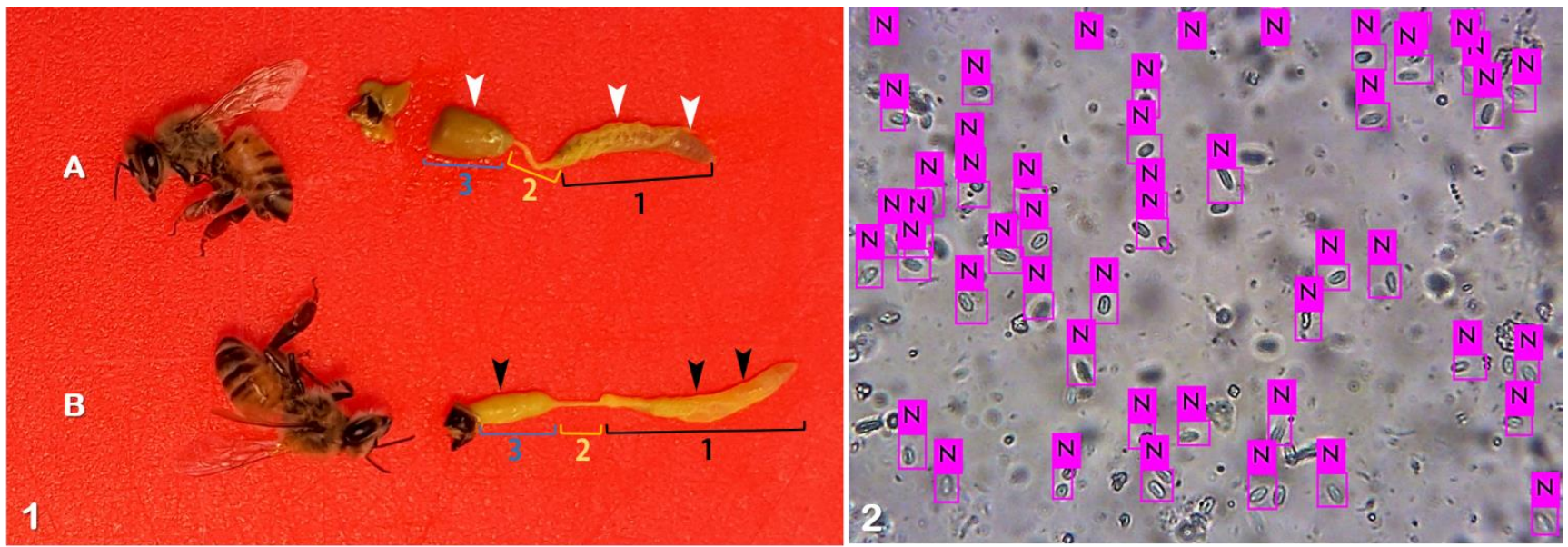

Şekil 1: (1) Sağlıklı (A) (kahvrengi içerik ve kalın duvar yapısı, beyaz ok başları) ve enfekte (B) (soluk renkli içerik ve incelmiş duvar yapısı, siyah ok başları) işçi arılara ait mide ve bağırsağın makroskobik görünümü. (2) Tüm abdomen homojenatlarındaki Nosema spp. sporları (N). 400x.

Figure 1: (1) General macroscopic appearance of the midgut and hindgut of healthy (A) (mid-gut with fine walls and filled with brownish excrements, white arrowheads) and infected $(B)$ (mid-gut with thin walls and filled with pale excrements,black arrowheads) worker bee. (2) Nosema spp. spores(N)in whole abdomen homogenates. $400 x$.

\section{Bulgular}

Makroskobik incelemelerde abdomen bölümünün sağlıklı işçi arılarda normal bir görünüm sergilerken enfekte arılarda şişerek genişlediği görüldü. Abdomenin diseksiyonu sonrasında sağlıklı işçi arıların mide duvarının kalınlığını koruduğu ve mide içeriğinin doğal kahverengi tonlarında olduğu gözlemlenirken; enfekte işçi arıların mide duvarının inceldiği (zar benzeri, şeffaf görünüm) ve mide içeriğinin renginin daha soluk ve akışkan kıvam aldığı tespit edildi. Sağliklı işçi arılarda bağırsak mukozasının bütünlüğünü koruduğu ve sekresyonun kuvvetli olduğu görüldü. Sağliklı işçi arıların mide epitel hücrelerinin, hücre membranlarının belirgin olduğu ve bütünlüklerini korudukları tespit edildi. Hücre çekirdekleri ise normal görünüm sergilerken sitoplazmaları homojen ve yoğun bir yapıya sahipti. Epitel hücrelerinde herhangi bir yıkımlanma görülmezken; peritrofik membranın oldukça kalın, yoğun ve lümenin tümünde eşit bir dağılım gösterdiği görüldü. Enfekte işçi arılarda ise nosema invazyonuna bağlı olarak mide mukozasında dejeneratif ve litik süreçlerin işlediği tespit edildi. Hücre içi osmotik basıncın artmasına bağlı olarak hücre membranlarının zarar gördüğü ya da tamamen patladığı dikkati çekti. Bu duruma bağlı olarak hücreler arasındaki sınırların ve bağlantıların kaybolduğu gözlemlendi. Bazı hücrelerde hücre çekirdeğinin ortadan kaybolduğu görüldü. Hücre sitoplazmalarının homojen görünümünü kaybettiği ve çeşitli büyüklüklerde vakuoller içerdiği fark edildi. Bunun yanı sıra enfekte mukozalarda polisakkarit sekresyonunda belirgin olarak zayıflama olduğu görüldü. Peritorik membranın yapısının gevşediği, hacmini kaybederek dağınık bir görünüm sergilediği tespit edildi. (Şekil 2).

Sağlıklı işçi arıların epitel hücrelerinin apikal yüzleri ve peritofik membranın nötral mukosubstans (PAS+), karboksilli ve sülfatlı asidik mukosubstans $(\mathrm{AB}+)$, nötral ve asidik mukosubstans (PAS+/AB+), asidik mukosubstans $(\mathrm{TB}+)$ yönünden kuvvetli bir pozitif boyanma profili gösterdiği tespit edildi. Bazı peritorfik membranlardaki mukosubstansın boyanma karakterinin yer yer değişiklik gösterdiği fark edildi. Mukosubstansın, enfekte işçi arılarda, sağlıklı olanlar ile benzer yerleşim gösterdiği tespit edildi. Yapılan boyamalarda enfekte işçi arıların mukosubstans yanıtı açısından, tamamen negatif olmamakla birlikte, daha zayıf bir reaksiyon verdiği görüldü (Şekil 2). 


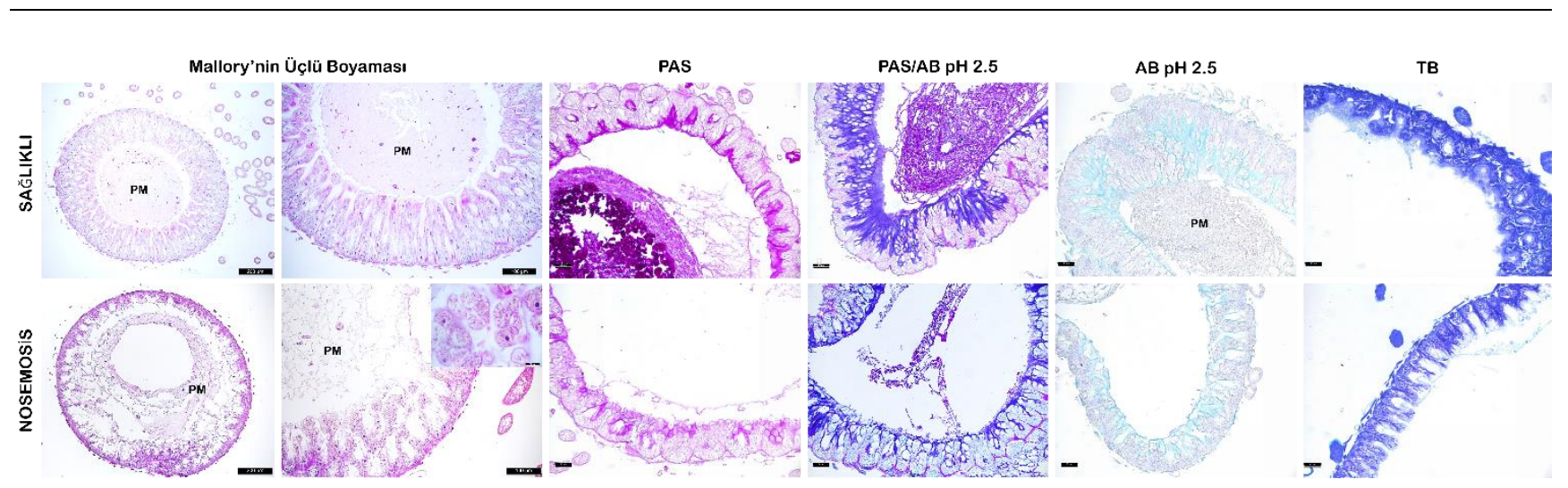

Şekil 2: Sağlıklı ve enfekte işçi arı midelerinin genel mikroskobik görünümü ile mukosubstansın yerleşimi ve dağılımı (PM: Peritrofik membran). Bar: $100 \mu \mathrm{m}$

Figure 2: General microscopic view of healthy and infected worker bee midguts and location and appearance of mucosubstance (PM: Peritrophic membrane). Scale bar: $100 \mu \mathrm{m}$

\section{Tartışma ve Sonuç}

Türkiye bal üretiminde dünyanın sayılı ülkeleri arasında yer almasına rağmen kovan başına bal veriminde sorunlar yaşamaktadır (22). Bunun en büyük nedenlerinden biri, arıların sağlığını doğrudan etkileyen hastalıklardır (15). Bal arısının yeterli düzeyde gelişimini tamamlaması ve yağ oranını arttırabilmesi için tükettiği polenlerin uygun bir şekilde sindirilerek emilmesi gerekmektedir (10). Bu mekanizmanın sağlıklı bir şekilde çalışabilmesi için mide epiteli çok kritik bir rol üstlenmektedir. Mide epitel hücreleri tarafından salgılanan mukosubstansın, sindirilmemiş içeriğin lubrikasyonu, osmoregülasyonun düzenlenmesi, proteinlerin, iyonların ve diğer maddelerin geçişlerinin sağlanması, epitelin mekanik etkiler ve patojenlerin invazyonundan korunması gibi birçok önemli fonksiyonu bulunmaktadır (8). Nosemosisli arılar üzerinde yapılan çalışmalarda salgılanan mukosubstansın karakterinin değiştiği ve nötral, karboksilli ve sülfatlı asidik mukosubstansın miktarında azalma olduğu tespit edilmiştir (7, 10, 23). Bizim çalışmamızda benzer şekilde farklı histokimyasal boyama yöntemleriyle incelen mukosubstans salgısının nosemosisli arılarda genel olarak değiştiği ve zayıfladığı görüldü. Bu durum, nosemosisli arılarda protein emiliminin bozulmasına bağlı olarak, glikozaminoglikanlar, glikoproteinler ve proteinlerden zengin olan mukosubstans salgısını da olumsuz etkilemiş olduğu düşünülmektedir.

Hücre içi bir patojenle enfekte olan hücrelerin, doğal yanıt olarak, bu durumu algıladıkları aşamada apoptotik hücre ölümü mekanizmalarını çalıştırarak bu etkenin çoğalma ve yayılma ihtimallerini önlediği tespit edilmiştir. Ancak yapılan çalışmalar özellikle microsporidiaların enfekte ettikleri hücrelerin metabolizmalarını başarılı şekilde manipüle ederek kendi yaşam döngüsünü devam ettirebildiği göstermiştir $(11,24)$. Bizim çalışmamızda elde edilen veriler neticesinde Nosema spp. ile enfekte olan bir çok mide epitel hücresinin kaçınılmaz olarak hücre ölümü yoluna gittiği ve buna bağlı olarak da peritrofik membranın yapısının da bozulduğu ve sekresyonunda azalmalar olduğu görülmüştür. Çalışmamızda gözlemlediğimiz hücre ölüm tipinin daha çok hücre nekrozu morfolojisi sergilemiş olması, bu etkenin son aşamaya kadar hücrenin kontrol mekanizmlarından kendisini saklamaya başardığı fikrini desteklemektedir. Ancak elde edilen sonucun sağlıklı bir şekilde doğrulanabilmesi için apoptotik ve nekrotik hücre ölüm tiplerinin daha detaylı yöntemlerle incelenmesi gerekmektedir.

Gajger ve ark (23) yaptıkları bir çalışmada nosemosisli arılarda PM'nın yapısının gevşeyerek bütünlüğünü kaybettiğini göstermişlerdir. Çalışmamızda benzer bir şekilde nosemosisli arılarda peritrofik membranın belirgin şekilde hacmini kaybederek dağınık bir görünüm kazandığı fark edildi. Peritrofik membranın mide epitel hücreleri olan yakın ilişikisi göz önünde bulundurulduğunda, Nosema sporlarılla enfekte olan epitel hücrelerinin ölümünün peritorfik membranında benzer bir yıkımlanma sürecine girmesine neden olabileceği düşünüldü. 
Arıların mide mukozası yaşam döngüsü boyunca birçok farklı patojen ve diğer olumsuz etkenlere maruz kalmaktadır. Bu çalışmada, bal arılarının mide epitel hücrelerine yerleşerek nosemosise neden olan Nosema spp.'nin mide mukozası üzerinde meydana getirdiği olumsuz değişikler histokimyasal ve histomorfolojik olarak incenlenmiştir. Çalışma sonucunda elde edilen veriler mide epitelinin hastalığın etikisiyle büyük oranda zarar görerek hücre ölümü sürecine girdiğini ve mukosubstansın üretiminin azalarak karakterinin değiştiğini göstermiştir. Nosemosise bağl1 meydana gelen hücre ölümünün tiplendirilmesi ve mukosbustans üretiminin azalmasına etki eden mekanizmaların ortaya konulması için yeni çalışmaların yapılması gerekmektedir.

\section{Kaynaklar}

1. Zander E (1909): Tierische parasiten als krankheitserreger bei der biene. Münchener Bienenzeitung, 31, 196-204. 2. Fries I, Feng F, da Silva A, Slemenda SB, Pieniazek NJ (1996): Nosema ceranae (Microspora, Nosematidae), morphological and molecular characterization of a microsporidian parasite of the Asian honey bee Apis ceranae (Hymenoptera, Apidae). Eur J Protistol, 32, 356-365.

3. Gajger I, Kozaric Z, Berta D, Nejedli S, Petrinec Z (2011): Effect of the herbal preparation Nozevict on the midgut structure of honeybees (Apis melifera) infected with Nosema sp. spores. Vet Med-Czech, 56 (1), 344-351.

4. Paxton RJ (2010): Does infection by Nosema ceranae cause "Colony Collapse Disorder" in honey bees (Apis mellifera)?. J Apic Res, 49 (1), 80-84.

5. Santos CG, Serrão JE (2006): Histology of the ileum in bees (Hymenoptera, Apoidea). Braz J Morphol Sci, 23, 405-413.

6. Szymaś B, Langowska A, Kazimierczak-Baryczko M (2012): Histological structure of the midgut of honey bees (Apis mellifera L.) fed pollen substitutes fortified with probiotics. J Apic Sci, 56 (1), 5-12.

7. Gajger I, Kozaric Z, Berta D, Nejedli S, Petrinec Z (2011): Effect of the herbal preparation Nozevict on the midgut structure of honeybees (Apis melifera) infected with Nosema sp. Spores. Veterinary Med, 56, 344-351.

8. Das Dores Teixeira A, Marques-Araújo S, Zanuncio JC, Serrão JE (2015): Peritrophic membrane origin in adult bees (Hymenoptera): Immunolocalization. Micron, 68, 91-97.

9. Jariyapan N, Saeung A, Intakhan N, Chanmol W, Sor-suwan S, Phattanawiboon B, Taai K, Choochote W (2013): Peritrophic matrix formation and Brugia malayimicrofilaria invasion of the midgut of a susceptible vector, Ochlerotatus togoi (Diptera Culicidae). Parasitol Res, 112, 2431-2440.

10. Dussaubat C, Brunet JL, Higes M, Colbourne JK, Lopez J, Choi JH, Bonnet M (2012): Gut pathology and responses to the microsporidium Nosema ceranae in the honey bee Apis mellifera. PloS One, 7(5).

11. Martin-Hernandez R, Higes M, Sagastume S, Juarranz A, Dias-Almeida J, Budge GE, Boonham N (2017): Microsporidia infection impacts the host cell's cycle and reduces host cell apoptosis. PLoS One, 12(2).

12. Gençer HV, Furatlı Ç (1999): Orta Anadolu ekotipleri (A. m. anatoliaca) ve Kafkas ırkı (A. m. caucasica) bal arılarının morfolojik özellikleri. Turk J Vet Anim Sci, 23(1), 107-113.

13. Güler A, Kaftanoğlu O, Bek Y, Yeninar H (1999): Türkiye'deki önemli balarısı (Apis mellifera L.) trk ve ekotiplerinin morfolojik karakterler açısından ilişkilerinin diskriminant analiz yöntemiyle saptanması. Turk J Vet Anim Sci, 23, 337-343.

14. Güler A, Toy H (2008): Sinop ili türkeli yöresi balarıları (Apis mellifera L.) ' nın morfolojik özellikleri. OMÜ Zir Fak Dergisi, 23(3), 190-197.

15. Doğaroğlu M (2009): Modern arıcılık teknikleri. 4. Basım, Türkmenler Matbaacılık, Tekirdağ.

16. Kekeçoğlu M (2010): Türkiye'deki bal arısı çeşitliliği. Ordu Arıcılık Dergisi, 4, 5-8.

17. Ütük AE, Pişkin FÇ, Kurt M (2010): Türkiye'de Nosema ceranae'nın ilk moleküler tanısı. Ankara Üniv Vet Fak Derg, 57, 275-278.

18. Tunca RI, Oskay D, Gosterit A, Tekin OK (2016): Does Nosema ceranae Wipe Out Nosema apis in Turkey?. Iran J Parasitol, 11(2), 259. 
19. OIE (2008): Nosematosis of honey bees. Erişim adresi:

https://www.oie.int/fileadmin/Home/eng/Health_standards/tahm/3.02.04_NOSEMOSIS_FINAL.pdf . Erişim tarihi: 2 Ocak 2020.

20. Crossmon G (1937): A modification of Mallory's connective tissue stain with a discussion of the principles involved. Anat Rec, 241, 155.

21. Ceylan A, Sevin S, Özgenç Ö (2019): Histomorphological and histochemical structure of the midgut and hindgut of the Caucasian honey bee (Apis mellifera caucasia). Turk J Vet Anim Sci, 43(6), 747-753.

22. TURKSTAT (2019): Hayvansal üretim. Türkiye İstatistik Kurumu. Erişim adresi: http://www.tuik.gov.tr/VeriBilgi.do?tb_id=46\&ust_id=13. Erişim tarihi: 2 Ocak 2020.

23. Gajger IT, Petrinec Z, Pinter L, Kozarić Z (2009): Experimental treatment of nosema disease with "Nozevit" phyto-pharmacological preparation. Am Bee J, 149, 485-490.

24. Higes M, Juarranz Á, Dias Almeida J, Lucena S, Botías C, Meana A, Martín Hernández R (2013): Apoptosis in the pathogenesis of Nosema ceranae (Microsporidia: Nosematidae) in honey bees (Apis mellifera). Environ Microbiol Rep, 5(4), 530-536. 